\title{
HPLC/MS-TOF Analysis of Surface Resins from Three Poplar Clones Grown in Serbia
}

\author{
Branislav Trudić ${ }^{1 *}$, Boban Anđelković ${ }^{2}$, Saša Orlović ${ }^{1}$, Vele Tešević ${ }^{2}$, Andrej Pilipović ${ }^{1}$, Mirjana Cvetković $^{3}$, \\ Jovana Stanković ${ }^{3}$
}

(1) University of Novi Sad, Institute of Lowland Forestry and Environment, Antona Čehova 13d, RS-21000 Novi Sad, Serbia; (2) University of Belgrade, Faculty of Chemistry, Centre for Instrumental Analysis, Studentski trg 12-16, RS-11158, Belgrade, Serbia; (3) University of Belgrade, Institute of Chemistry, Technology and Metallurgy, Njegoševa 12, RS-11000, Belgrade, Serbia

*Correspondence: e-mail: btrudic@uns.ac.rs
Citation: TRUDIĆ B, ANĐELKOVIĆ B, ORLOVIĆ S, TEŠEVIĆ V, PILIPOVIĆ A, CVETKOVIĆ M, STANKOVIĆ J 2016 HPLC/ MS-TOF Analysis of Surface Resins from Three Poplar Clones Grown in Serbia. South-east Eur for 7 (2): 129-133. DOI: https://doi.org/10.15177/seefor.16-12

Received: 26 Jul 2016; Revised: 26 Aug 2016; Accepted: 29 Aug 2016; Published online: 6 Sep 2016

\begin{abstract}
Background and Purpose: Poplar clones grown in Serbia are fast growing tree species important for many different purposes in forestry and industry. In this study chemical content of the surface resins of three poplar clones grown in Serbia - M1, B229 and PE 19/66 was analyzed, aiming at their potential usage as a source of natural products important for pharmacy and chemotaxonomy.

Materials and Methods: Using HPLC/MS-TOF we gained the first information on chemical compounds which comprise of resins on terminal twigs cuttings of commonly grown poplar clones. Provided from the nursery of the Institute of Lowland Forestry and Environment (Serbia), terminal twigs cuttings with leaves of different development stage from two year old seedlings of M1 poplar clone (Populus euramericana L.), PE 19/66 clone and B229 clone (both belonging to Populus deltoides) were sampled. The washing of the surface resins from terminal twigs cuttings of every sample was done with methylene-chloride until the samples were prepared for HPLC/MS-TOF analysis.

Results: Out of 38 different compounds which were identified, M1 clone qualitatively differed for 14 compounds as compared to two other clones. Generally, the results showed that the composition of the resins consisted of different phenolic acids, phenolic esters, flavonoids and other contents.

Conclusion: These three poplar clones are potent producers of pharmacologically and chemotaxonomically potent compounds in forest ecosystems, especially M1 clone.
\end{abstract}

Keywords: phenols, poplars, resins, terminal twigs

\section{INTRODUCTION}

The genus Populus from Salicaceae family consists of about 30 species, growing in southern and central Europe, in central Asia, Siberia, and North America, characterized and differentiated by the presence of different flavonoids, phenolic derivatives, and terpenoids in particular in young leaves, buds, and bud exudates [1]. Several species of Populus have been traditionally used in medicine, especially for their antiinflammatory properties [2]. Nowadays, large-scale poplar production is based on clone culture production of controlled hybrids. The complex chemistry of poplar bud exudates includes about a hundred different phenolic and terpenoid compounds
[3], several of which are involved in biological processes [1] Poplar biomass is a potential resource for natural production of bioactive molecules which could be substituted for some synthetic compounds associated with human and animal medicine [1]. Buds from Populus species are the main source of resins in propolis in Europe and North America ("poplar type" propolis) [4]. Resins comprising flavonoids and related phenolic acids represent approximately half of the propolis constituents [5]. Still, the chemical composition of the bee glue is extremely dependent on the plants found around the hive, as well on the geographic and climatic characteristics of the site. 
Less commonly, species such as Betula, Ulmus, Pinus, Quercus, Salix and Acacia are also used in the production of propolis by bees $[6,7]$. For the first time, the chemical composition of the cuticular waxes of poplar clones from Serbia was done and the results of GC/MS analysis showed that there are no significant differences in presence of alkanes: $n$-nonacosane, $n$-hexacosane, $n$-untriacosane and $n$-octacosane within leaf wax of these three clones [8].

Chemical content of the surface resins from three poplar clones was in the focus of this research. This type of chemical analysis of the surface resins from any fast-growing tree species from Serbia has previously not been undertaken.

\section{MATERIALS AND METHODS}

\section{The Sampling of Plant Material}

Five terminal twigs cuttings with healthy leaves of different development stage from two year old seedlings of M1 (Panonnia) poplar clone (Populus euramericana L.), cl. PE 19/66 and cl. B229 (both belonging to Populus deltoides) were sampled at the same time from the nursery collection of the Institute of Lowland Forestry and Environment, University of Novi Sad. The collections were grown as separate plantations, consisting of seedlings of the same age and origin, and influenced by the same climatic and weather conditions since they have been grown in the open. The two Populus deltoides clones B-229 and PE 19/66, and the hybrid P. x canadensis clone $\mathrm{M}-1$ have previously been reported to be suitable for high biomass plantations [9-11]. Populus deltoides clones such as PE 19/66 were showed greater net photosynthesis than hybrid poplars (e.g. M-1), but hybrids were superior in water use efficiency [12]. The collections are part of the experimental Kać Forest estate located north-east from the city of Novi Sad, near the Kać village (N45 $17^{\prime} 41^{\prime \prime}$ E19 $53^{\prime}$ $\left.30^{\prime \prime}\right)$. The genetic structure of the M1 and B229 clones has previously been determined through SSR and AFLP marker system and published, confirming the specific DNA profile of two different species originating from this nursery collection [13]. As the objective of the study was to examine the chemical composition and not the variability between single plants, the results were obtained for one pooled sample of terminal twigs cuttings with leaves from five plants per cultivar.

\section{Preparation of Resin Extracts}

Terminal twigs cuttings were immediately transported in sterile plastic bottles ( $5 \mathrm{~mL}$ volumes) on ice to laboratories of the Centre for Instrumental Analysis in Belgrade. Poplar clones' surface resins were washed out from the terminal shoots with $10 \mathrm{~mL}$ dichlormethane. Afterwards, the extracts were evaporated under a stream of $\mathrm{N}_{2}$ for 23 minutes and dissolved in methanol at a concentration of $10 \mathrm{mg} / \mathrm{mL}$, respectively.

\section{HPLC/MS-TOF Analysis}

High-resolution Liquid Chromatography/Photo-Diode Array/Electro Spray/Time of Flight mass spectra (HRLC/PDA/ $\mathrm{ESI} / \mathrm{TOF} \mathrm{MS}$ ) were measured on a HPLC instrument (Agilent 1200 Series) equipped with an autosampler, using a Zorbax Eclipse Plus C18 analytical column (1.8 $\mu \mathrm{m}$ particle size, $4.6 \times$ $150 \mathrm{~mm}$ i.d., Agilent Technologies), and a PDA detector (DAD) coupled with a 6210 TOF LC/MS system (Agilent Technologies).

The mobile phase for HRLC/PDA/ESI/TOF MS was $0.2 \%$ formic acid in water (A) and acetonitrile (B), and analyses were carried out under the following conditions: (0-3 $\mathrm{min}) 10 \% \mathrm{~B}$, (3-8 $\mathrm{min}$ ) $10-25 \% \mathrm{~B},(8-11 \mathrm{~min}) 25 \% \mathrm{~B},(11-18 \mathrm{~min}) 25-30 \% \mathrm{~B}$, (18-48 min) $30-40 \%$ B, (48-68 min) $40-60 \%$ B, (68-88 min) 60$90 \% \mathrm{~B},(88-100 \mathrm{~min}) 90 \% \mathrm{~B},(100-101 \mathrm{~min}) 90-10 \% \mathrm{~B}$, and (101$120 \mathrm{~min}) 10 \% \mathrm{~B}$. The flow rate was $1.20 \mathrm{~mL} \cdot \mathrm{min}^{-1}$, the injection volume was $5 \mu \mathrm{L}$, while the temperature of the column oven was set at $40^{\circ} \mathrm{C}$. UV Spectral data from all peaks were accumulated in the range of $190-450 \mathrm{~nm}$ and chromatograms were recorded at $280 \mathrm{~nm}$. MS data have been collected by applying the following parameters: ionization, negative ESI capillary voltage $4000 \mathrm{~V}$, gas temperature $350^{\circ} \mathrm{C}$, drying gas $12 \mathrm{~L} \cdot \mathrm{min}^{-1}$, nebulizer pressure $45 \mathrm{psi}$, fragmentor voltage 140 $\mathrm{V}$, mass range $100-2000 \mathrm{~m} / \mathrm{z}$. A personal computer system running MassHunter Workstation software was used for data acquisition and processing.

Exact mass measurements of pseudomolecular ions of analytes performed with a time-of-flight (TOF) mass spectrometer in negative polarity mode enabled the determination of molecular formula of most of the constituents. All identified compounds exhibited quasi-molecular ion [M$\mathrm{H}]^{-}$in the negative mode, confirming the molecular mass. Peak identification was mainly tentative, by comparison of their retention time, mass, and UV spectra with the literature data. For nine compounds we had standards for additional conformation of identification.

\section{RESULTS AND DISCUSSION}

Thirty-eight different compounds in resin extract of M1 clone and 24 common compounds within resin extract of B229 and PE 19/66 clones (Table 1, Figure 1) were identified. Fourteen compounds were unique for M1 clone, giving possibility to use them as potential species specific chemotaxonomic markers. Those are the compounds belonging to the caffeic, coumaryl and pinobaksin groups of compounds.

Our HPLC/MS-TOF analysis confirmed that Serbian poplar clones mainly consists of three groups of phenolic compounds: phenolic acids (caffeic acid, p-coumaric acid, cynammic acid), phenolic esters, and flavonoid aglycons of flavanones (pinocembrin, pinobaksin), flavonols (galangin, quercaetin and kaempferol), flavones (chrysin and its derivates, apigenin). We have also identified salycilate like populin. The results obtained in the experiment were compared with literature data on $P$. nigra HPLC bud and propolis analysis in the following text. Black poplar buds are coated with a viscous substance, an exudate which contains different varieties of phenolic compounds: flavonoid aglycons and their chalcones and phenolic acids and their esters [2]. Also, the chemical characterization of bud exudate has allowed the identification among the flavonoid aglycons of some flavanones such as pinocembrin and pinostrobin, some flavonols such as galangin, quercetin and kaempferol, some flavones such as chrysin and apigenin [14-16] and some esters of phenolic acids, similar to our data when it comes to the phenolic content. Such compounds have also been reported in propolis [17]. Bud extract of $P$. nigra was mainly composed of phenolic acids (caffeic, $p$-coumaric, ferulic, 
TABLE 1. A list of identified compounds within surface resins of three poplar clones. Abbreviation NI means Not Identified. Compounds marked with * were previously reported in Trudić et al. [20]. Bolded compounds are compounds identified by internal standards.

\begin{tabular}{|c|c|c|c|c|c|c|c|c|}
\hline No. & UV max & $\begin{array}{l}\text { Quasi-molecular } \\
\text { ion [M-H] }\end{array}$ & $\begin{array}{l}\text { Exact } \\
\text { mass }\end{array}$ & $\begin{array}{l}\text { Molecular } \\
\text { formula }\end{array}$ & Compound name & $\begin{array}{c}\text { M1 } \\
\text { Clone }\end{array}$ & $\begin{array}{l}\text { B229 } \\
\text { Clone }\end{array}$ & $\begin{array}{l}\text { PE19/66 } \\
\text { Clone }\end{array}$ \\
\hline 1 & $198 ; 216 ; 274$ & 109,0287 & 110,0360 & $\mathrm{C}_{6} \mathrm{H}_{6} \mathrm{O}_{2}$ & Benzenediol & + & + & + \\
\hline 2 & $198 ; 216 ; 274$ & 123,0442 & 124,0515 & $\mathrm{C}_{7} \mathrm{H}_{8} \mathrm{O}_{2}$ & Methyl benzenediol & + & + & + \\
\hline 3 & $230 ; \operatorname{sh} 296 ; 324$ & 179,0341 & 180,0414 & $\mathrm{C}_{9} \mathrm{H}_{8} \mathrm{O}_{4}$ & Caffeic acid $*$ & + & + & + \\
\hline 4 & $\operatorname{sh} 290,310$ & 163,0372 & 164,1445 & $\mathrm{C}_{9} \mathrm{H}_{8} \mathrm{O}_{3}$ & $p$-Coumaric acid * & + & + & + \\
\hline 5 & $244 ;$ sh296; 322 & 423,1294 & 424,1364 & $\mathrm{C}_{20} \mathrm{H}_{24} \mathrm{O}_{10}$ & Furanocoumarin & + & + & + \\
\hline 6 & $234 ; 288$ & 285,0762 & 286,0835 & $\mathrm{C}_{16} \mathrm{H}_{14} \mathrm{O}_{5}$ & Pinobaksin-5-methyl-ethar & + & + & + \\
\hline 7 & $242 ; 268 ; 300$ & 389,1226 & 390,1309 & $\mathrm{C}_{20} \mathrm{H}_{22} \mathrm{O}_{8}$ & Populin* & + & + & + \\
\hline 8 & 292 & 271,0604 & 272,0677 & $\mathrm{C}_{15} \mathrm{H}_{12} \mathrm{O}_{5}$ & Naringenin * & + & + & + \\
\hline 9 & $264 ; 310$ & 267,0654 & 268,0727 & $\mathrm{C}_{16} \mathrm{H}_{12} \mathrm{O}_{4}$ & Chrysin-5-methyl-eter & + & + & + \\
\hline 10 & $264 ; 338$ & 269,0452 & 270,0525 & $\mathrm{C}_{15} \mathrm{H}_{10} \mathrm{O}_{5}$ & Apigenin * & + & + & + \\
\hline 11 & 292 & 271,0604 & 272,0676 & $\mathrm{C}_{15} \mathrm{H}_{12} \mathrm{O}_{5}$ & Pinobaksin * & + & + & + \\
\hline 12 & $266 ; 364$ & 285,0396 & 272,0676 & $\mathrm{C}_{15} \mathrm{H}_{10} \mathrm{O}_{6}$ & Kaempferol * & + & + & + \\
\hline 13 & $236 ; 288$ & 269,0812 & 270,0885 & $\mathrm{C}_{16} \mathrm{H}_{14} \mathrm{O}_{4}$ & $\mathrm{NI}$ & + & + & + \\
\hline 14 & $254 ; 372$ & 315,0504 & 316,0576 & $\mathrm{C}_{16} \mathrm{H}_{12} \mathrm{O}_{7}$ & Isorhamnetin & + & + & + \\
\hline 15 & $264 ; 348$ & 299,0554 & 300,0626 & $\mathrm{C}_{16} \mathrm{H}_{12} \mathrm{O}_{6}$ & Luteolin-3'methyl-ethar & + & + & + \\
\hline 16 & $254 ; 356$ & 329,0660 & 330,0733 & $\mathrm{C}_{17} \mathrm{H}_{14} \mathrm{O}_{7}$ & Quercetin-dimethyl-ethar & + & + & + \\
\hline 17 & $260 ; 302 ; 352$ & 283,0603 & 284,0676 & $\mathrm{C}_{16} \mathrm{H}_{12} \mathrm{O}_{5}$ & Galangin-methyl-ethar & + & + & + \\
\hline 18 & $232 ; 286 ; 324$ & 327,0869 & 328,0942 & $\mathrm{C}_{18} \mathrm{H}_{16} \mathrm{O}_{6}$ & Pinobaksin-5-methyl-ethar-3-acetate & + & + & + \\
\hline 19 & 244; 294sh; 326 & 315,0844 & 316,0919 & $\mathrm{C}_{17} \mathrm{H}_{16} \mathrm{O}_{6}$ & $\mathrm{NI}$ & + & & \\
\hline 20 & $268 ; 312$ & 253,0497 & 254,0570 & $\mathrm{C}_{15} \mathrm{H}_{10} \mathrm{O}_{4}$ & Chrysin & + & + & + \\
\hline 21 & $296 ; 326$ & 247,0967 & 248,1040 & $\mathrm{C}_{14} \mathrm{H}_{16} \mathrm{O}_{4}$ & Caffeic acid prenyl ester & + & & \\
\hline 22 & 294 sh; 328 & 269,0810 & 270,0883 & $\mathrm{C}_{16} \mathrm{H}_{14} \mathrm{O}_{4}$ & Caffeic acid benzyl ester & + & & \\
\hline 23 & 290 & 255,0655 & 256,0728 & $\mathrm{C}_{15} \mathrm{H}_{12} \mathrm{O}_{4}$ & Pinocembrin & + & + & + \\
\hline 24 & $266 ; 360$ & 269,0445 & 270,0518 & $\mathrm{C}_{15} \mathrm{H}_{10} \mathrm{O}_{5}$ & Galangin & + & + & + \\
\hline 25 & 290 & 285,0760 & 286,0833 & $\mathrm{C}_{16} \mathrm{H}_{14} \mathrm{O}_{5}$ & Pinobaksin-7-O-methyl eter & + & & \\
\hline 26 & 294 & 313,0712 & 314,0784 & $\mathrm{C}_{17} \mathrm{H}_{14} \mathrm{O}_{4}$ & Pinobaksin-3-0-acetate & + & + & + \\
\hline 27 & $298 ; 328$ & 283,0968 & 284,1041 & $\mathrm{C}_{17} \mathrm{H}_{16} \mathrm{O}_{4}$ & Caffeic acid Phenylethyl eter & + & & \\
\hline 28 & $264 ; 312$ & 283,0603 & 284,0676 & $\mathrm{C}_{16} \mathrm{H}_{12} \mathrm{O}_{5}$ & Methoxy-Chrysin & + & + & + \\
\hline 29 & 230; 290sh; 310 & 231,1015 & 232,1088 & $\mathrm{C}_{14} \mathrm{H}_{16} \mathrm{O}_{3}$ & $p$-Coumaryl prenyl ester & + & & \\
\hline 30 & $220 ; 314$ & 253,0861 & 254,0935 & $\mathrm{C}_{16} \mathrm{H}_{14} \mathrm{O}_{3}$ & $p$-Coumaryl benzyl ester & + & & \\
\hline 31 & 220; 288sh; 312 & 231,1017 & 232,1089 & $\mathrm{C}_{14} \mathrm{H}_{16} \mathrm{O}_{3}$ & $p$-Coumaryl prenyl ester & + & & \\
\hline 32 & $248 ; 316$ & 295,0967 & 296,1040 & $\mathrm{C}_{18} \mathrm{H}_{16} \mathrm{O}_{4}$ & Caffeic acid cinnamyl ester & + & & \\
\hline 33 & $238 ; 232$ sh; 324 & 311,2222 & 312,2294 & $\mathrm{C}_{18} \mathrm{H}_{32} \mathrm{O}_{4}$ & $\mathrm{NI}$ & + & & \\
\hline 34 & 294 & 327,0868 & 328,0941 & $\mathrm{C}_{18} \mathrm{H}_{16} \mathrm{O}_{6}$ & Pinobaksin-3-0-propionate & + & & \\
\hline 35 & 314 & 267,1017 & 268,1090 & $\mathrm{C}_{17} \mathrm{H}_{16} \mathrm{O}_{3}$ & $p$-Coumaryl phenylethyl ester & + & & \\
\hline 36 & $268 ; 312$ & 279,1016 & 280,1097 & $\mathrm{C}_{18} \mathrm{H}_{16} \mathrm{O}_{3}$ & $p$-Coumaryc cinnamyl ester & + & & \\
\hline 37 & 294 & 341,$1020 ; 377,0788$ & 342,1093 & $\mathrm{C}_{19} \mathrm{H}_{18} \mathrm{O}_{6}$ & Pinobaksin-3-0- butyrate & + & & \\
\hline 38 & 292 & 355,$1172 ; 391,0958$ & 356,1245 & $\mathrm{C}_{20} \mathrm{H}_{20} \mathrm{O}_{6}$ & Pinobaksin -3-O pentanoate & + & & \\
\hline
\end{tabular}

isoferulic, di-O-methyl caffeic and cinnamic acids) (5.2\%), followed by salicylates (salicin) (1.8\%) and flavonoid aglycons (pinobaksin 5-methyl ethar, pinobaksin and pinocembrin) (1.5\%) [18].

Data comparison of poplar bud absolute markers after true quantitation by derivatization-GC-MS and HPLC-PDA was also reported in study of Rubiolo et al. [18]: benzoic acid, cinnamic acid, $p$-methoxycinnamic acid, $p$-coumaric acid, dimethoxycinnamic acid, isoferulic acid, ferulic acid, caffeic acid, 1,1-dimethylallyl caffeate, pinostrobin, pinocembrin, tectochrysin, chrysin, galangin. Salicyl aldehyde in fresh $0.2 \%$ and in dried $1.4 \%$ plant material of $P$. nigra $L$. was also identified in study of Jerković and Mastelić [15]. This compound may originate from salicin and/or populin by hydrolysis and oxidation and as mentioned before, we identified populin in our resins extract. Jerković and Mastelić [15] have also 
XWC of DAD Spectral Data: 280.0 nm from BA_PE19_66_Propolis3_ZEPC18_RRMK140V_neg1.wiff
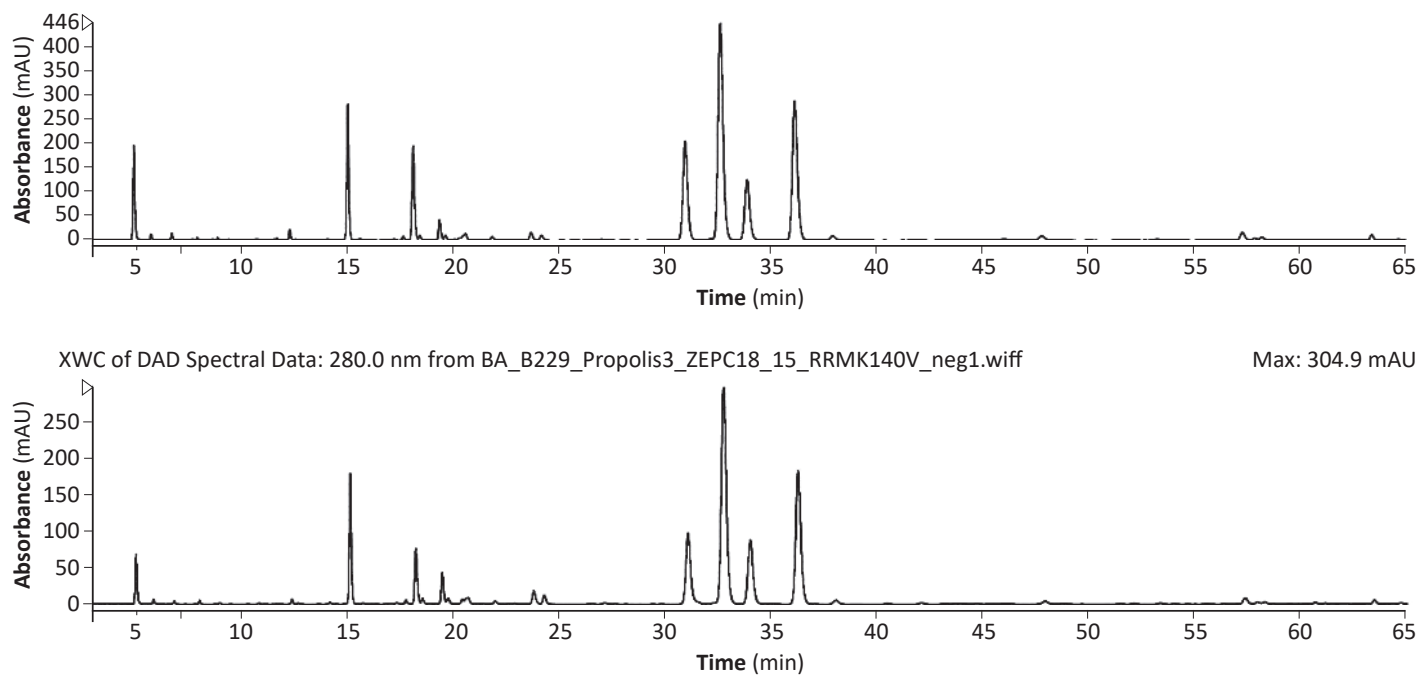

XWC of DAD Spectral Data: 260.0 nm from BA_M1_Propolis3_ZEPC18_15_RRMK140V_neg1.wiff

Max: $140.4 \mathrm{mAU}$

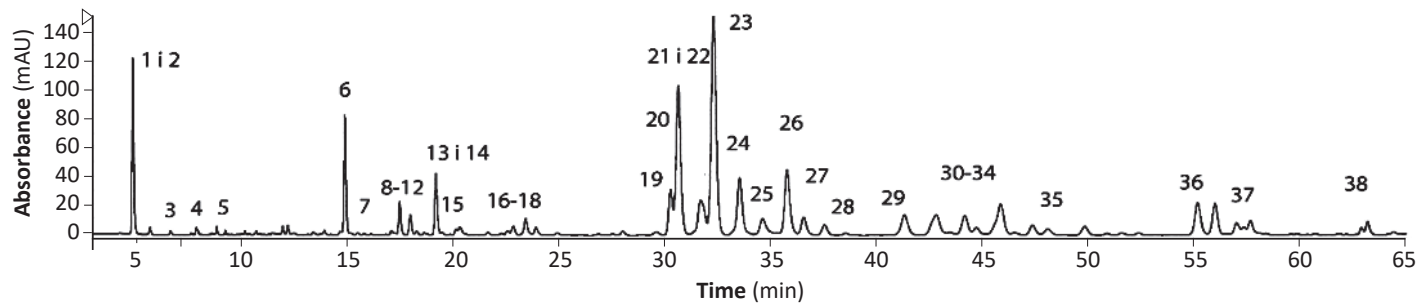

FIGURE 1. DAD chromatograms of identified resin compounds measured on $280 \mathrm{~nm}, 65$ minutes. Peak numbers refer to those reported in Table 1.

reported prenyl alcohols with higher percentage (7.6\%) in dried buds. Non-terpenes presented $9.8-13.5 \%$ of the total isolate. The gross compositions of non-terpenes were aliphatic and aromatic alcohols, carbonyl compounds and aliphatic acids. Benzyl alcohol and 2-phenylethanol were previously identified (ca. $0.2 \%$ ) in the bud extract of $P$. candicans [19]. The analysis of the phenolic extract of Portuguese propolis allowed the detection of dihydroflavonols, flavones, flavanones and flavonols, either as a free form or their methylated/esterified forms [7]. In particular, it was possible to identify the aglycones forms of apigenin, pinobaksin, pinocembrin and chrysin, the esterified derivatives pinobaksin-3-O-acetate, pinobaksin3-O-propionate, pinobaksin-2-O-butyrate or isobutyrate and pinobaksin-3-0-pentanoate or 2-methylbutyrate and the methylated derivatives pinobaksin-5-methyl-ethar, pinocembrin-5-methyl-ethar, chrysin-5-methyl-ethar, and chrysin-6-methyl-ethar. In propolis from temperate zones, the most frequently reported phenolic acids are caffeic acid, ferulic acid and the cinnamic acid [4]. We reported the following esters and ethar derivates: $p$-cinamyc cinamyl ester, pinobaksin-3-0butyrate, pinobaksin-3-0 pentanoate, pinobaksin-5-methylethar, luteolin-3-methyl-ethar, quercetin-dimethyl-ethar, galangin-methyl-ethar, pinobaksin-5-methyl-ethar-3-acetate, caffeic acid prenyl ester, caffeic acid benzyl ester, pinobaksin7-methyl-eter, pinobaksin-3-0-acetate, 2-phenylethyl caffeate, coumaril prenil ester, coumaril benzyl ester, coumaril prenil ester, caffeic acid cinnamyl ester, pinobaksin-3-0-propionate. Similarity with the chemical profile of $P$. nigra might indicate that some of those phenolic compounds and its ester might be common for the genus Populus, but further analysis within more Populus species is needed to confirm such hypothesis.

\section{CONCLUSIONS}

Direct assessment of antioxidant activity of resins is required through FRAP, DPPH, ORAC, ABTS, lipid peroxidation and other tests to screen its radical scavenging capacity and correlate it with quantity analysis of its bioactive compounds. In this case, $70 \%$ ethanol should be used as a common and nontoxic solvent for extraction. It is also possible that isomers can be present, although further NMR analysis must be performed.

The results presented in this study shows application in: 
- Chemical compounds identified so far can be applied in pharmaceutical research and thus involve more nursery production of poplar clones' biomass as a resource of those molecules;

- To understand the chemical profile of propolis, since resins are the starting material for its production by bees;

- Chemotaxonomy, since we confirmed that there is a quite different chemical profile of surface resins between two species of poplars from our collection. In our study, 14 compounds were specifically characteristic for M1 clone ( $P$. euramericana L) surface resin extract, indicating their species-specific significance. However, further comparative study with other poplar species is needed to determine the presence/absence of those compounds within genus.

- To monitor and predict poplar's biomass pharmacological potential and label them as a nursery with ecosystem service significance.

\section{Acknowledgements}

This study was conducted under the support of the Ministry of Education, Science and Technological Development of the Republic of Serbia. The authors declare that they have no conflict of interest.

\section{REFERENCES}

1. WARNANT P, MERTENS P, MARCHE C 2004 Screening of poplar biomass for bio-active compounds: a simple method to assess antioxidant activity. Bioresource Technol 93 (1): 43-48. DOI: http://dx.doi.org/10.1016/i. biortech.2003.10.006

2. DUDONNE $S$, POUPARD $P$, COUTIERE P, WOILLEZ $M$, RICHARD T, MERILLON J-M, VITRAC, X 2011 Phenolic Composition and Antioxidant Properties of Poplar Bud (Populus nigra) Extract: Individual Antioxidant Contribution of Phenolics and Transcriptional Effect on Skin Aging. J Agr Food Chem 59 (9): 4527-4536. DOI: http://dx.doi. org/10.1021/if104791t

3. GREENAWAY W, MAY J, WHATLEY FR 1989 Flavonoid aglycones identified by gas chromatography-mass spectrometry in bud exudate of Populus balsamifera. J Chromatogr 472: 393-400. DOI: http://dx.doi.org/10.1016/ S0021-9673(00)94139-6

4. MARCUCCI MC 1995 Propolis: chemical composition, biological properties and therapeutic activity. Apidologie 26 (2): 83-99. DOI: http://dx.doi.org/10.1051/ apido:19950202

5. BANKOVA VS, DE CASTRO SL, MARCUCCI MC 2000 Propolis: recent advances in chemistry and plant origin. Apidologie 31 (1): 3-15. DOI: http://dx.doi.org/10.1051/ apido:2000102

6. KÖNIG B 1985 Plant sources of propolis. Bee World 66 (4): 136-139. DOI: http://dx.doi.org/10.1080/000577 2X.1985.11098844

7. FALCÃO SI, VILAS-BOAS M, ESTEVINHO LM, BARROS C, DOMINGUES MRM, CARDOSO SM 2010 Phenolic characterization of Northeast Portuguese propolis: usual and unusual compounds. Anal Bioanal Chem 396 (2): 887 897. DOI: http://dx.doi.org/10.1007/s00216-009-3232-8

8. TRUDIĆ B, ANDELKOVIĆ B, TEŠEVIĆ V, ORLOVIĆ S, JADRANIN MB, KRSTIĆ G, GALOVIĆ V 2013 Chemical analysis of leaf cuticular wax of poplar clones in Serbia. Topola (Poplar) 191-192: 63-72

9. ANDRAŠEV S, RONČEVIĆ S, BOBINAC MT 2003 Effect of planting density on diameter structure of black poplar clones S6-7 and M-1 - section Aigeiros (Duby). Glasnik Šumarskog fakulteta 88: 7-16. DOI: http://dx.doi. org/10.2298/GSF0388007A (in Serbian with English summary)
10. KOVAČEVIĆ B, RONČEVIĆ S, MILADINOVIĆ D, IVANIŠEVIĆ P, KATANIĆ M 2009 Early shoot and root growth dynamics as indicators for the survival of black poplar cuttings. New For 38 (2): 177-185. DOI: http://dx.doi.org/10.1007/s11056009-9138-7

11. KLAŠNJA B, ORLOVIĆ S, GALIĆ Z 2012 Energy potential of poplar plantations in two spacings and two rotations. Šumar List 136 (3-4): 161-167

12. ORLOVIĆ S, PAJEVIĆ SP, KRSTIĆ ĐB 2002 Selection of black poplars for water use efficiency. Proceedings for Natural Sciences, Matica Srpska, Novi Sad (Zbornik Matice Srpske za Prirodne Nauke) 102: 45-51. DOI: http://dx.doi. org/10.2298/ZMSPN02010450

13. ORLOVIĆ S, GALOVIĆ V, ZORIĆ Z, KOVAČEVIĆ B, PILIPOVIĆ A, GALIĆ Z. 2009 Evaluation of interspecific DNA variability in poplars using AFLP and SSR markers. African Journal of Biotechnology 8 (20): 5241-5247. DOI: http://dx.doi. org/10.5897/AJB09.1071

14. GREENAWAY W, WHATLEY FR 1991 Synthesis of esters of acetyloxycaffeic acids and their occurrence in poplar bud exudates. J Chromatogr 543: 113-121. DOI: http://dx.doi. org/10.1016/S0021-9673(01)95759-0

15. JERKOVIĆ I, MASTELIĆ J 2003 Volatile compounds from leaf-buds of Populus nigra L. (Salicaceae). Phytochemistry 63 (1): 109-113. DOI: http://dx.doi.org/10.1016/S00319422(02)00706-9

16. MATTES BR, CLAUSEN TP, REICHARDT PB 1987 Volatile constituents of balsam poplar: the phenol glycoside connection. Phytochemistry 26 (5): 1361-1366. DOI: http:// dx.doi.org/10.1016/S0031-9422(00)81813-0

17. ISIDOROV VA, VINOGOROVA VT 2003 GC-MS analysis of compounds extracted from buds of Populus balsamifera and Populus nigra. Z Naturforsch 58 (5-6): 355-360

18. RUBIOLO P, CASETTA C, CAGLIERO C, BREVARD $\mathrm{H}$, SGORBINI B, BICCHI C 2013 Populus nigra L. bud absolute: a case study for a strategy of analysis of natural complex substances. Anal Bioanal Chem 405 (4): 1223-1235. DOI: http://dx.doi.org/10.1007/s00216-012-6537-y

19. WHATELY FR, GREENWAY W, MAY J 1989 Populus candicans and the balm of Gilead. Z Naturforsch 44 (5-6): 353-356

20. TRUDIĆ B, ANĐELKOVIĆ B, ORLOVIĆ S, TEŠEVIĆ V, CVETKOVIĆ M, STANKOVIĆ J 2015 Preliminary biochemical analysis of M1 (Panonnia) poplar clone surface resins. In: Proceedings of International Symposium "Forest and Sustainable Development", Brasov, Romania,. Transilvania University Press, Brasov, Romania, pp 69-74 